\title{
Site-Selective Phosphoglycerate Mutase 1 Acetylation by a Small Molecule
}

Xiaodan Zhang ${ }^{\prime \#}$, Lulu Jiang ${ }^{1 \#}$, Ke Huang ${ }^{1 \#}$, Chuantao Fang ${ }^{2}$, Jian Li $^{2}$, Jintong Yang ${ }^{1}$, Huiti $\mathrm{Li}^{1}$, Xiaoxue Ruan', Penghui Wang ${ }^{1}$, Mingguang $\mathrm{Mo}^{1}$, Ping $\mathrm{Wu}^{3}$, Yanhui $\mathrm{Xu}^{4}$, Chao Peng ${ }^{3}$, Motonari Uesugi ${ }^{1,5}$, Deyong $\mathrm{Ye}^{\mathrm{1}^{*}}$, Faxing Yu${ }^{2^{*}}$, Lu Zhou ${ }^{{ }^{*}}$

1. Department of Medicinal Chemistry, School of Pharmacy, Fudan University, Shanghai 201203, China.

2. Children's Hospital and Institutes of Biomedical Sciences, Fudan University, Shanghai 200032, China.

3. National Facility for Protein Science in Shanghai, Zhangjiang Lab, Shanghai 201210, China.

4. Fudan University Shanghai Cancer Centre, Institute of Biomedical Sciences, Shanghai Medical College of Fudan University, Shanghai 200032, China.

5. Institute for Integrated Cell-Material Sciences (WPI-iCeMS), Institute for Chemical Research, Kyoto University, Uji, Kyoto 611-0011, Japan.

${ }^{\#}$ These authors contributes equally to this work.

Corresponding Author

dyye@shmu.edu.cn; fxyu@fudan.edu.cn; zhoulu@fudan.edu.cn

This file include General considerations, Scheme 1-2, Table 1-5, Figure S1-S5, References, Materials and Methods.

\section{General considerations}


All reagents were purchased from Sinopharm Chemical Reagent Co.,Ltd, Xiya Reagent and used without further purification. Column chromatography was conducted on silica gel (300-400 mesh). 1H NMR and 13C NMR spectra were recorded on Bruker AC400 and Bruker AC600 NMR spectrometer respectively in which tetramethylsilane served as an internal reference. Low-resolution mass analysis was performed on Agilent 6120 Quadrupole mass spectrometer (electrospray positive ionization; ESI) using Agilent liquid-chromatography mass spectrometer system. High-resolution mass spectra was carried out on a triple TOF 5600+ MS/MS system (AB Sciex, Concord, Ontario, Canada) in the negative ESI mode.

Primers were commercially synthesized inCompany. PCR was carried out with S1000TM Thermal Cycler (BioRad). Restriction enzymes, DNA polymerase, DNA ligase and reaction buffers were used.. For DNA purification, TEGEN quick Mini Purification Kit was used. For the plasmid amplification, the competent cell DH5 $\alpha$ was used. For plasmid extraction from bacteria, Miniprep kit (TEGEN, \#DP103) was used. DNA sequencing analysis was carried outby company.. For the plasmid mutation, Quick change kit (TRANGEN BIOTECH, \#FM111-02) was used. For SDS-PAGE running, VE-186 electrophoresis chamber was purchased and carried out at $120 \mathrm{~V}$.

For western blot, Tanon ${ }^{\mathrm{TM}}$ High-sig ECL Western Blotting Substrate were used. Protein concentration was measured by BCA Protein Assay Kit by and DNA concentration was measured by NanoDrop2000. The antibody that was used in the experiment was purchased from Abcam, sigma, CST. The specific antibody was generated commercially.

\section{Scheme 1}




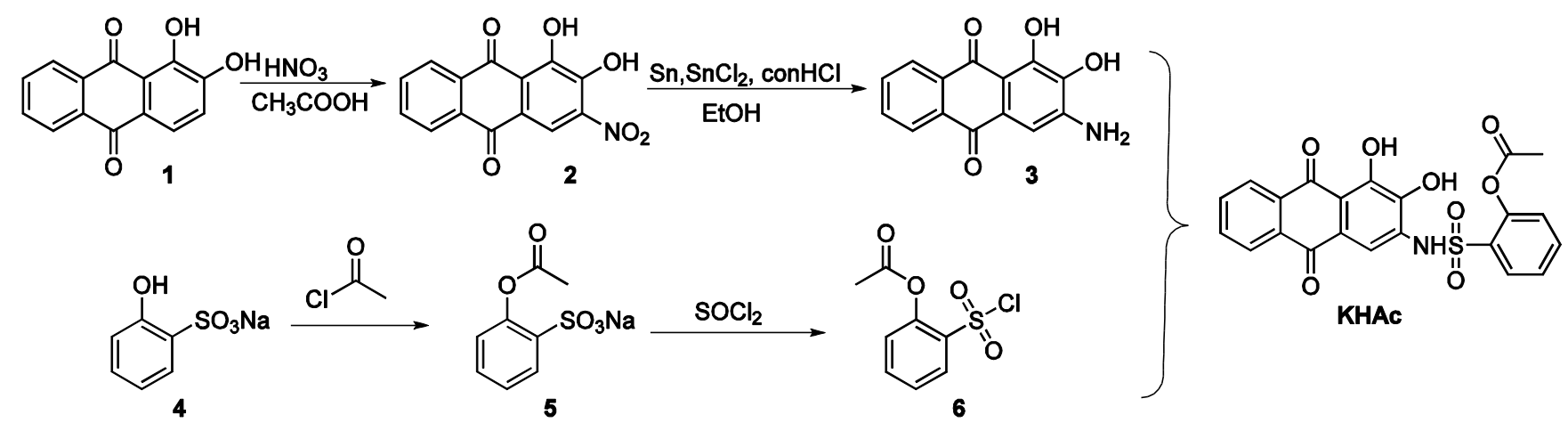

Synthesis of 1, 2-dihydroxy-3-nitroanthracene-9, 10-dione (2)

The suspension of 1,2-dihydroxyanthracene-9,10-dione( $5 \mathrm{~g}, 20.8 \mathrm{mmol})$ in acetic acid $(350 \mathrm{ml})$ at $50^{\circ} \mathrm{C}$ was treated with nitric $\operatorname{acid}(1.5 \mathrm{ml}, 33.33 \mathrm{mmol})$. The mixture was then left overnight at room temperature and filtered to get a yellow solid $(4.15 \mathrm{~g}, 70 \%)(\mathrm{w} / \mathrm{w})$ of crude product $2^{[1]}$.

Synthesis of 3-amino-1, 2-dihydroxyanthracene-9, 10-dione (3)

To the suspension of 1,2-dihydroxy-3-nitroanthracene-9,10-dione (1.75 g, $6.14 \mathrm{mmol})$ in ethanol (350 ml), $\mathrm{SnCl}_{2} \cdot 2 \mathrm{H}_{2} \mathrm{O}(12.5 \mathrm{~g}, 55.4 \mathrm{mmol})$, Sn (10.5 g, $\left.341 \mathrm{mmol}\right)$ and concentrated $\mathrm{HCl}(50.4 \mathrm{ml}, 604.8 \mathrm{mmol})$ were added. The mixture was stirred overnight at room temperature and poured into water $(1 \mathrm{~L})$. A red solid precipitated and was filtered, dried under vacuum to get a black solid $(1.41 \mathrm{~g}, 90 \%)(\mathrm{w} / \mathrm{w})$ of crude product $\mathbf{3}^{[1]}$.

\section{Synthesis of sodium 2-acetoxybenzenesulfonate (5)}

Sodium 2-hydroxybenzenesulfonate (2 $\mathrm{g}, 10 \mathrm{mmol})$ was added to acetyl chloride (10 $\mathrm{ml})$ and stirred at $50^{\circ} \mathrm{C}$ for $5 \mathrm{~h}$. The solution was concentrated under reduced pressure to get a yellowish oil of crude product 5 .

\section{Synthesis of 2-(chlorosulfonyl) phenyl acetate (6)}


Sulfurous dichloride $(10 \mathrm{ml})$ and a drop of $\mathrm{N}, \mathrm{N}$-dimethylformamide were added to the crude product 5 and stirred for 5 hours. The solution was concentrated under reduced pressure to get a gray oil of crude product 6 .

\section{Synthesis of 2-(N-(3,4-dihydroxy-9,10-dioxo-9,10-dihydroanthracen-2-yl)sul- famoyl)phenyl acetate (KHAc)}

To the solution of 3-amino-1,2-dihydroxyanthracene-9,10-dione (255 $\mathrm{mg}, 1 \mathrm{mmol})$ in dry pyridine $(5 \mathrm{ml})$, the crude product 6 was added dropwise and stirred at room temperature for $4 \mathrm{~h}$. Then the solution was added to $10 \%(\mathrm{w} / \mathrm{w})$ aqueous $\mathrm{HCl}(50 \mathrm{ml})$, extracted with ethyl acetate, washed with brine, dried over anhydrous $\mathrm{Na}_{2} \mathrm{SO}_{4}$, filtered and concentrated under reduced pressure. The residue was purified by silica chromatography to obtain KHAc as a yellow solid (197 mg, 40\%) (w/w). 1H NMR (400 MHz, DMSO-d6): $\delta 8.07-$ $7.96(\mathrm{~m}, 2 \mathrm{H}), 7.83-7.70(\mathrm{~m}, 4 \mathrm{H}), 7.63(\mathrm{~s}, 1 \mathrm{H}), 7.22(\mathrm{~d}, \mathrm{~J}=8.5 \mathrm{~Hz}, 2 \mathrm{H}), 2.14(\mathrm{~s}, 3 \mathrm{H}) .13 \mathrm{C}$ NMR (151 MHz, DMSO): $\delta$ 187.44, 180.50, 168.58, 161.36, 153.43, 150.00, 142.36, 134.71, 133.98, 133.16, 132.72, 128.96, 128.17, 126.56, 126.16, 123.47, 122.65, 115.49, 112.50, 112.07, 111.62, 20.68. HRMS: HRMS calcd $\mathrm{C}_{22} \mathrm{H}_{15} \mathrm{NO}_{8} \mathrm{~S}$ [M-H]-, 452.0446; found, 452.0450

\section{Scheme 2}

Synthetic route of KHAc-5C-N 3 
$\mathrm{Brr}_{\mathrm{HO}}+\mathrm{NaN}_{3} \underset{\text { dry DMF }}{\stackrel{\text { ice bath } \longrightarrow \text { r.t }}{\longrightarrow}} \underbrace{\mathrm{HO}_{\mathrm{N}_{3}}}_{7}$

$\underbrace{\mathrm{SO}_{3} \mathrm{Na}}_{\mathrm{DOF}}$

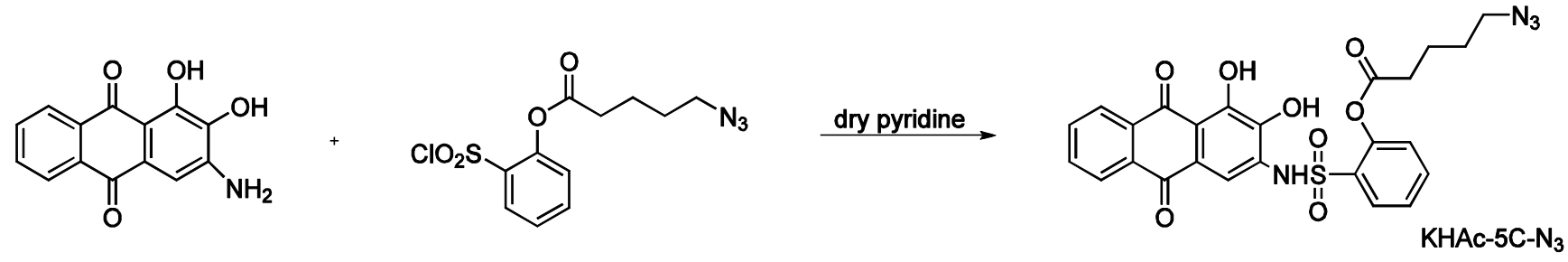

\section{Synthesis of 5-azidopentanoic acid (7)}

5-bromopentanoic acid (905 $\mathrm{mg}, 5 \mathrm{mmol}$ ) was dissolved in $25 \mathrm{ml}$ dimethyl formamide (DMF) under ice bath. Sodium azide was added to the solution and stirred till all the powdery solid was completely dissolved. The reaction was then kept overnight under the room temperature. The mixture was adjusted to $\mathrm{pH} 2 \sim 3$ by using the $1 \mathrm{M}$ hydrochloric acid and extracted with ether. The organic layer was washed with brine, dried over anhydrous $\mathrm{Na}_{2} \mathrm{SO}_{4}$, filtered and concentrated under reduced pressure to get crude product 7 as a white solid.

\section{Synthesis of sodium 2-((azidopentanoyl)oxy) benzenesulfonate (8)}

Sodium 2-hydroxybenzenesulfonate $(196 \mathrm{mg}, 1.625 \mathrm{mmol}$ ) and 4-dimethylaminopyridine (39.7 $\mathrm{mg}, 0.325 \mathrm{mmol}$ ) were dissolved in $9 \mathrm{ml}$ DMF on ice bath, and 5-azidopentanoic acid (302 mg, $2.112 \mathrm{mmol}$ ) was added to the mixture. N, N'-dicyclohexylcarbodiimide (435 mg, $2.112 \mathrm{mmol}$ ) was then added and stirred until the powdery solid was completely dissolved. The reaction was then moved to room temperature and kept overnight. The $\mathrm{pH}$ of mixture was adjusted to $2 \sim 3$ and white precipitate appeared. The mixture was filtered and the filtrate was concentrated under reduced pressure to remove the solvent. The residue 
was purified by silica chromatography to get the crude product of 2-((azidopentanoyl)oxy) benzenesulfonate without further purification.

\section{Synthesis of 2-(chlorosulfonyl) phenyl 5-azidopentanote (9)}

Sulfurous dichloride $(6 \mathrm{ml})$ and a drop of N, N-dimethylformamide were added to the crude product 8 and stirred for 5 hours under $85^{\circ} \mathrm{C}$. The solution was concentrated under reduced pressure to get a yellow oil of crude product 9.

\section{Synthesis of 2-(N-3,4-dihydroxy-9,10-dioxo-9,10-dihydroanthracen-2-yl) sulfamoyl) phenyl 5-azidopentanoate (KHAc-5C-N $\mathrm{N}_{3}$}

To the solution of 3-amino-1,2-dihydroxyanthracene-9,10-dione $(89.4 \mathrm{mg}, 0.35 \mathrm{mmol})$ in dry pyridine $(5 \mathrm{ml})$, the crude product 9 was added dropwise and stirred at room temperature for $4 \mathrm{~h}$. Then the solution was added to 10\% (w/w) aqueous $\mathrm{HCl}(50 \mathrm{ml})$, extracted with ethyl acetate, washed with brine, dried over anhydrous $\mathrm{Na}_{2} \mathrm{SO}_{4}$, filtered and concentrated under reduced pressure. The residue was purified by silica chromatography and KHAc-5C-N $\mathrm{N}_{3}$ as a maroon solid (42 mg, 22\%) (w/w) was obtained. 1H NMR (400 MHz, DMSO-d6) $\delta 8.17(\mathrm{t}, \mathrm{J}=4.3 \mathrm{~Hz}, 1 \mathrm{H}), 8.13(\mathrm{dd}, \mathrm{J}=5.7,3.0 \mathrm{~Hz}, 1 \mathrm{H}), 7.93(\mathrm{~d}, \mathrm{~J}=8.5 \mathrm{~Hz}$, 1H), $7.90(\mathrm{~s}, 1 \mathrm{H}), 7.75(\mathrm{~s}, 0 \mathrm{H}), 7.36(\mathrm{~d}, \mathrm{~J}=8.4 \mathrm{~Hz}, 1 \mathrm{H}), 2.62(\mathrm{t}, \mathrm{J}=7.0 \mathrm{~Hz}, 1 \mathrm{H}), 1.61$ (dp, J = 21.6, 7.4, 6.8 Hz, 2H). 13C NMR (101 MHz, DMSO-d6) $\delta$ 187.18, 180.10, $170.55,153.17,149.78,141.93,137.06,134.42$, 133.65, 132.78, 132.31, 130.67, 127.87, $126.22,125.83,123.23,122.30,112.67,112.42,111.88,49.79(\mathrm{~d}, \mathrm{~J}=13.0 \mathrm{~Hz}), 32.29$, 26.95, 20.87. HRMS calcd $\mathrm{C}_{25} \mathrm{H}_{20} \mathrm{~N}_{4} \mathrm{O}_{8} \mathrm{~S}[\mathrm{M}-\mathrm{H}]^{-}, 535.0929$; found, 535.0934: 


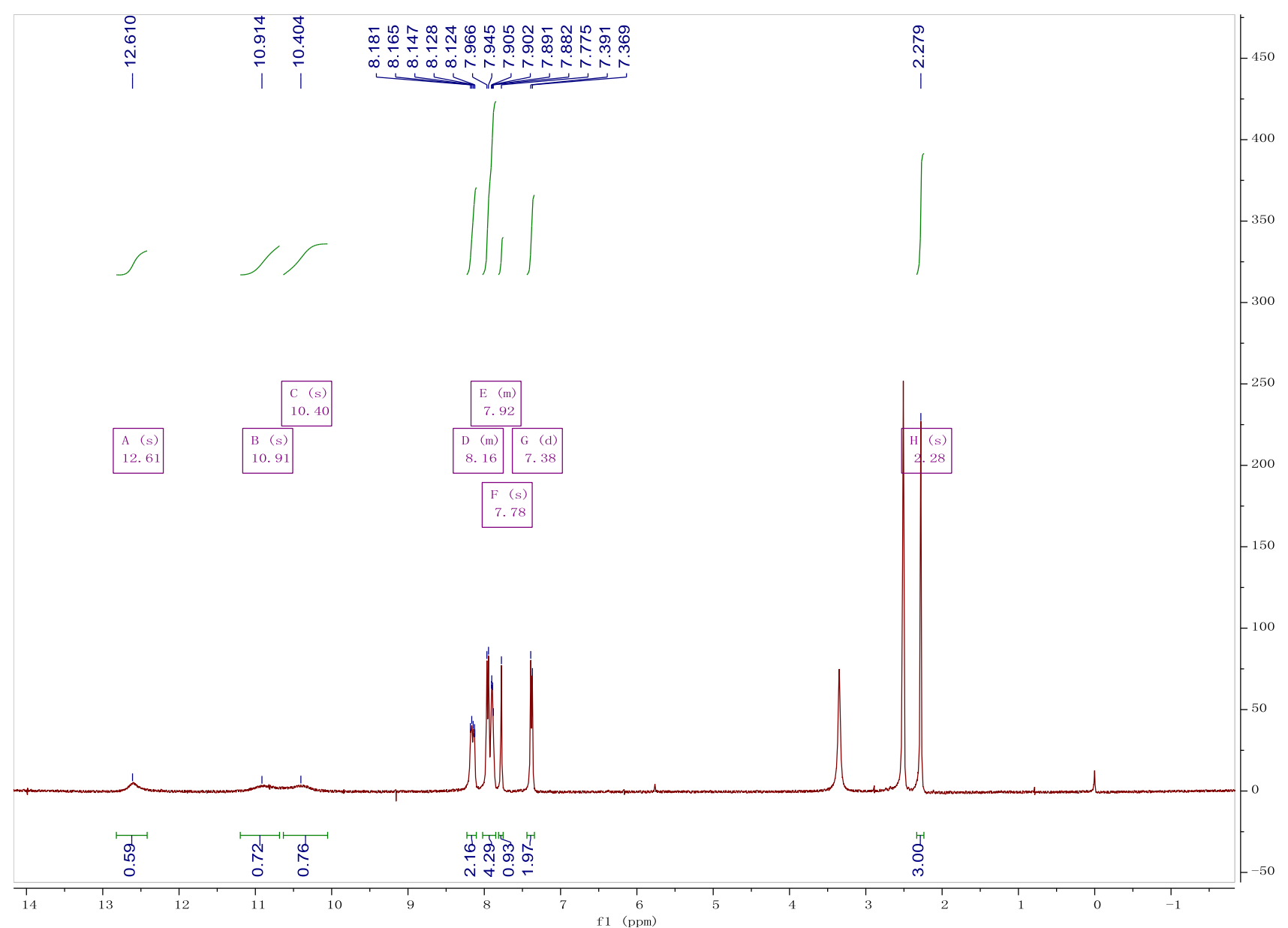




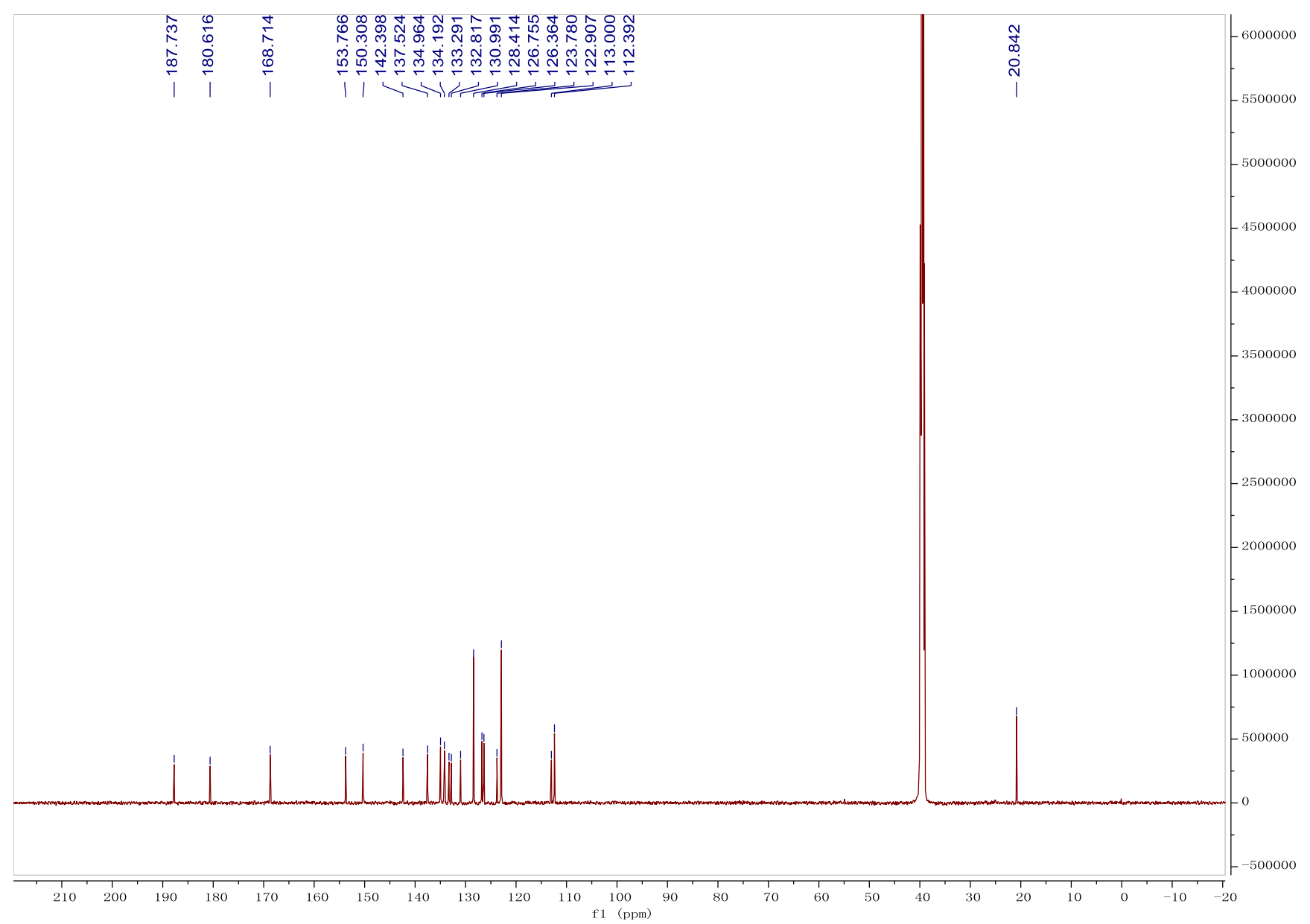

${ }^{1} \mathrm{H}-$ (TOP) and ${ }^{13} \mathrm{C}-($ Bottom) NMR spectrum of KHAc 
은 $\infty \infty_{\infty} \infty \infty^{\infty} \infty \infty^{\infty} \infty \infty^{\infty} \infty$

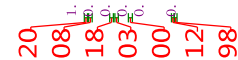

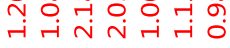
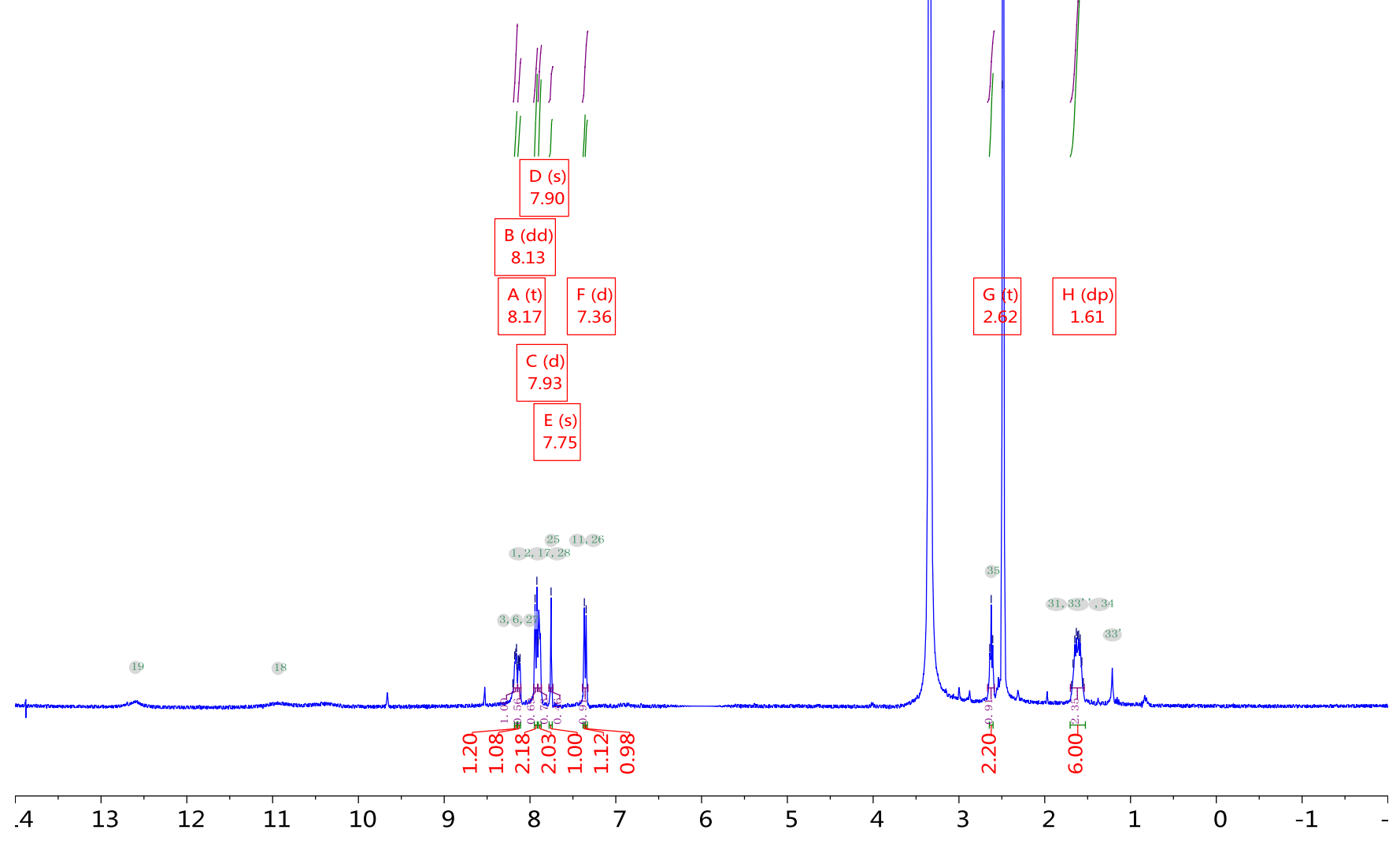

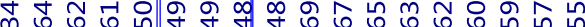
min 


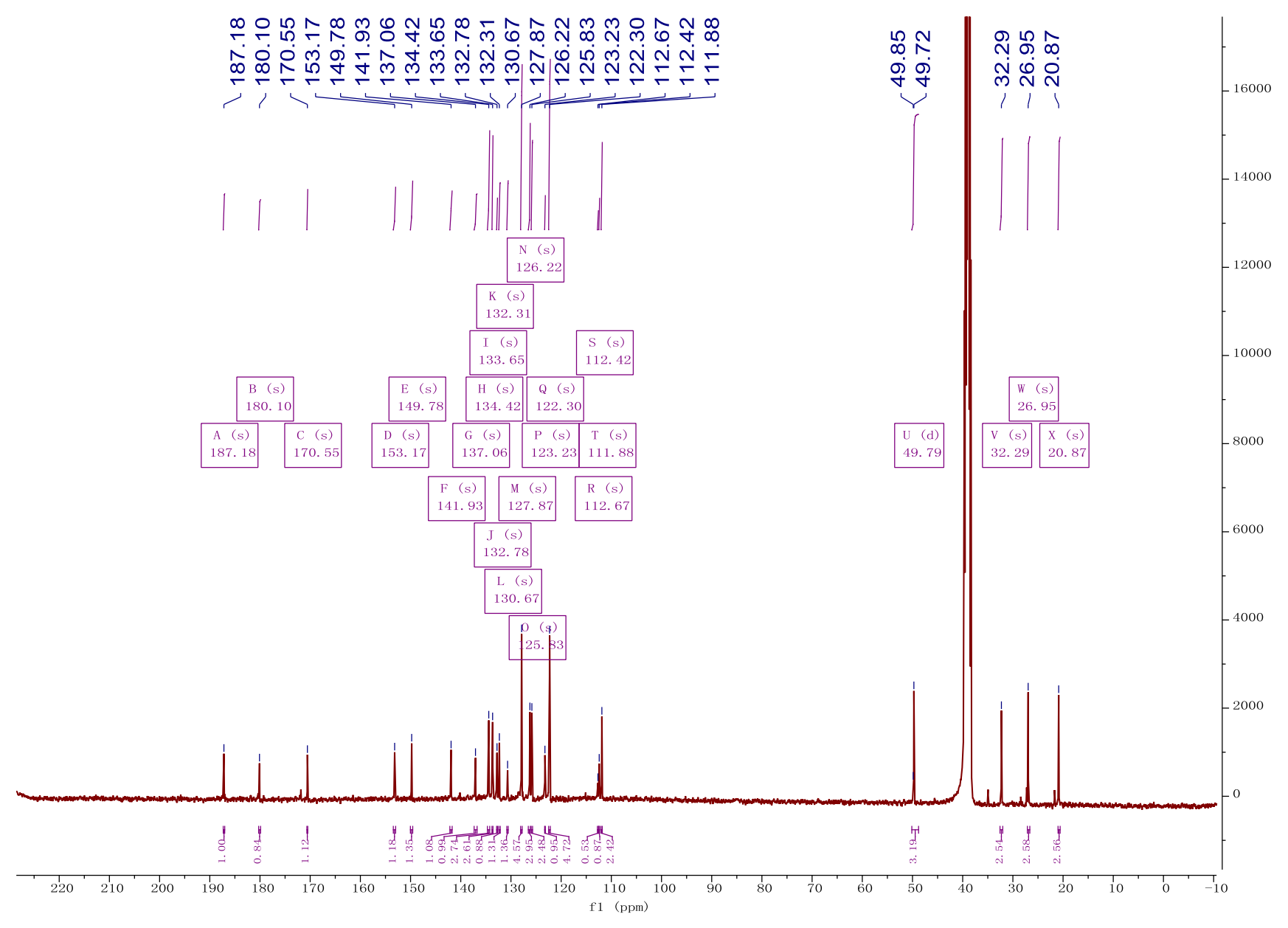

${ }^{1} \mathrm{H}-$ (TOP) and ${ }^{13} \mathrm{C}-($ Bottom) NMR spectrum of KHAc-5C-N 
Table S1 The acetylated lysine in PGAM1 treated with DMSO and KHAc

\begin{tabular}{|c|c|c|c|}
\hline & & $\begin{array}{c}\text { Spec count } \\
\text { PGAM1+DMS } \\
\text { O }\end{array}$ & $\begin{array}{c}\text { Spec count } \\
\text { PGAM1+HKAc }\end{array}$ \\
\hline \multirow[t]{2}{*}{ K4 } & un-acetyl & 1 & 2 \\
\hline & acetyl & 0 & 0 \\
\hline \multirow[t]{2}{*}{ K39 } & un-acetyl & 180 & 190 \\
\hline & acetyl & 0 & 14 \\
\hline \multirow[t]{2}{*}{ K61 } & un-acetyl & 58 & 52 \\
\hline & acetyl & 0 & 0 \\
\hline \multirow[t]{2}{*}{ K100 } & un-acetyl & 38 & 7 \\
\hline & acetyl & 3 & 127 \\
\hline \multirow[t]{2}{*}{ K106 } & un-acetyl & 15 & 114 \\
\hline & acetyl & 1 & 14 \\
\hline \multirow[t]{2}{*}{ K113 } & un-acetyl & 1 & 13 \\
\hline & acetyl & 5 & 197 \\
\hline \multirow[t]{2}{*}{ K138 } & un-acetyl & 197 & 206 \\
\hline & acetyl & 1 & 14 \\
\hline \multirow[t]{2}{*}{ K157 } & un-acetyl & 103 & 98 \\
\hline & acetyl & 3 & 8 \\
\hline \multirow[t]{2}{*}{ K176 } & un-acetyl & 88 & 76 \\
\hline & acetyl & 0 & 5 \\
\hline \multirow[t]{2}{*}{ K179 } & un-acetyl & 4 & 7 \\
\hline & acetyl & 0 & 0 \\
\hline \multirow[t]{2}{*}{ K195 } & un-acetyl & 203 & 223 \\
\hline & acetyl & 0 & 10 \\
\hline \multirow[t]{2}{*}{ K222 } & un-acetyl & 168 & 204 \\
\hline & acetyl & 5 & 7 \\
\hline \multirow[t]{2}{*}{ K225 } & un-acetyl & 341 & 324 \\
\hline & acetyl & 96 & 134 \\
\hline
\end{tabular}




\begin{tabular}{|l|l|r|r|}
\hline \multirow{2}{*}{ K228 } & un-acetyl & 441 & 455 \\
\cline { 2 - 4 } & acetyl & 23 & 29 \\
\hline K241 & un-acetyl & 39 & 85 \\
\cline { 2 - 4 } & acetyl & 0 & 4 \\
\hline
\end{tabular}

Table S2 The enzyme kinetics assay of PGAM1 with compound KHAc

\begin{tabular}{|l|l|l|l|}
\hline Compound & $\mathbf{K}_{\mathbf{i}}(\mathbf{n M})$ & $\mathbf{K}_{\text {inact }}\left(\mathbf{S}^{\mathbf{- 1}}\right)$ & $\mathbf{K}_{\text {inact }} / \mathbf{K}_{\mathbf{i}}\left(\mathbf{M}^{-\mathbf{1}} \cdot \mathbf{S}^{\mathbf{- 1}}\right)$ \\
\hline KHAc & 1235 & 11.46 & $9.28 \times 10^{3}$ \\
\hline
\end{tabular}

\section{Table S3 Data collection for different state of PGAM1}

\begin{tabular}{|c|c|c|c|}
\hline Property & $\begin{array}{c}\text { PGAM1 complex } \\
\text { with KHAc (2 hours) }\end{array}$ & $\begin{array}{c}\text { PGAM1 complex with } \\
\text { KHAc (7 hours) }\end{array}$ & $\begin{array}{c}\text { PGAM1 K100Ac (18 } \\
\text { hours) }\end{array}$ \\
\hline Space group & $\mathrm{P} 2_{1} 2_{1} 2_{1}$ & $\mathrm{P} 2_{1} 2_{1} 2_{1}$ & $\mathrm{P} 2_{1} 2_{1} 2_{1}$ \\
\hline
\end{tabular}




\begin{tabular}{|c|c|c|c|}
\hline $\begin{array}{l}\text { Cell constants } \\
\text { a, b, c }(\AA)\end{array}$ & 82.4282 .97103 .84 & 78.7483 .10100 .37 & 78.8382 .83100 .23 \\
\hline$\alpha, \beta, \gamma\left(^{\circ}\right)$ & $90.00,90.00,90.00$ & $90.00,90.00,90.00$ & $90.00,90.00,90.00$ \\
\hline Resolution * $(\AA)$ & $\begin{array}{c}50-2.28 \\
(2.36-2.28)\end{array}$ & $\begin{array}{c}50-2.20 \\
(2.28-2.20)\end{array}$ & $\begin{array}{c}50-2.68 \\
(2.78-2.68)\end{array}$ \\
\hline $\begin{array}{c}\text { Data completeness } \\
(\%)\end{array}$ & $99.7(99.5)$ & $99.9(100.0)$ & $99.5(98.0)$ \\
\hline No. Observations & 215193 & 216522 & 114668 \\
\hline $\begin{array}{l}\text { No. Unique Reflec- } \\
\text { tions }\end{array}$ & 33482 & 34426 & 19166 \\
\hline Redundancy & $6.4(6.0)$ & $6.3(6.4)$ & $6.0(4.7)$ \\
\hline $\mathrm{R}_{\text {merge }}$ & $0.07(0.62)$ & $0.08(0.80)$ & $0.15(0.81)$ \\
\hline$<\mathrm{I} / \sigma(\mathrm{I})>$ & 1.83 (at $2.27 \AA)$ & 1.83 (at $2.20 \AA$ ) & 1.97 (at $2.69 \AA$ ) \\
\hline
\end{tabular}

Table S4 Structure refinement statistical data different state of PGAM1

\begin{tabular}{|l|c|c|c|}
\hline \multirow{3}{*}{ Property } & $\begin{array}{c}\text { PGAM1 complex with } \\
\text { KHAc (2 hours) }\end{array}$ & $\begin{array}{c}\text { PGAM1 complex with } \\
\text { KHAc (7 hours) }\end{array}$ & $\begin{array}{c}\text { PGAM1 K100Ac (18 } \\
\text { hours) }\end{array}$ \\
& & & \\
\hline
\end{tabular}




\begin{tabular}{|c|c|c|c|}
\hline & PDB ID: 5ZRM & PDB ID: $5 Z \mathrm{~S} 8$ & PDB ID: $5 Z \mathrm{ZS} 7$ \\
\hline Space group & P 212121 & P 212121 & P 212121 \\
\hline $\begin{array}{l}\text { Cell constants } \\
\mathrm{a}, \mathrm{b}, \mathrm{c}, \alpha, \beta, \gamma\end{array}$ & $\begin{array}{c}82.42 \AA 82.97 \AA 103.84 \AA \\
90.00 \circ 90.00 \circ 90.00^{\circ}\end{array}$ & $\begin{array}{c}78.74 \AA 83.10 \AA 100.37 \AA \\
90.00^{\circ} 90.00^{\circ} 90.00^{\circ}\end{array}$ & $\begin{array}{c}78.83 \AA 82.83 \AA 100.23 \AA \\
90.00 \circ 90.00^{\circ} 90.00^{\circ}\end{array}$ \\
\hline Resolution $(\AA)$ & $\begin{array}{l}37.06-2.28 \\
(2.35-2.28)\end{array}$ & $\begin{array}{l}49.67-2.20 \\
(2.26-2.20)\end{array}$ & $\begin{array}{l}36.68-2.68 \\
(2.82-2.68)\end{array}$ \\
\hline $\begin{array}{c}\text { Data completeness } \\
(\%)\end{array}$ & $99.7(99)$ & $99.9(100)$ & $99.4(99)$ \\
\hline No. reflections & 33047 & 34053 & 18903 \\
\hline $\mathrm{R}_{\text {work }} / \mathrm{R}_{\text {free }}$ & $0.196 / 0.232$ & $0.179 / 0.220$ & $0.189 / 0.255$ \\
\hline $\mathrm{R}_{\text {free }}$ test set & 1685 reflections $(5.06 \%)$ & 1734 reflections $(5.05 \%)$ & 979 reflections $(5.15 \%)$ \\
\hline Wilson B-factor $\left(\AA^{2}\right)$ & 47.2 & 41.5 & 49.7 \\
\hline$F_{o}, F_{c}$ correlation & 0.95 & 0.96 & 0.94 \\
\hline $\begin{array}{l}\text { Total number of at- } \\
\text { oms }\end{array}$ & 3941 & 4114 & 3883 \\
\hline $\begin{array}{c}\text { Average } \mathrm{B} \text {, all atoms } \\
\qquad\left(\AA^{2}\right)\end{array}$ & 50.0 & 40.0 & 32.0 \\
\hline Ligands & $\begin{array}{l}\text { MES: } 1 ; \\
\text { KHAc: } 1 ; \\
\text { CL: } 1 ;\end{array}$ & $\begin{array}{c}\text { MES: } 1 ; \\
\text { KH_ol: } 1 ; \\
\text { CL: } 1 ;\end{array}$ & $\begin{array}{l}\text { MES: } 1 ; \\
\text { CL: } 1 ;\end{array}$ \\
\hline $\begin{array}{c}\text { Ramachandran fa- } \\
\text { vored }(\%)\end{array}$ & 97.6 & 97.7 & 96.3 \\
\hline $\begin{array}{c}\text { Ramachandran al- } \\
\text { lowed }(\%)\end{array}$ & 2.4 & 2.3 & 3.7 \\
\hline $\begin{array}{c}\text { Ramachandran outli- } \\
\text { ers (\%) }\end{array}$ & 0 & 0 & 0 \\
\hline Bond lengths $(\AA)$ & 0.008 & 0.008 & 0.008 \\
\hline Bond angles $\left({ }^{\circ}\right)$ & 1.010 & 1.045 & 1.183 \\
\hline
\end{tabular}

Table 5 The stability of KHAc under different condition (2 hours) 


\begin{tabular}{|c|c|c|}
\hline \multirow{4}{*}{ KHAc } & Buffer & Percentage content for 2 hours \\
\cline { 2 - 3 } & PBS $(\mathrm{pH} 7.4)$ & $100 \%$ \\
\cline { 2 - 3 } & DMEM $(10 \% \mathrm{FBS}, \mathrm{v} / \mathrm{v})$ & $83 \%$ \\
\cline { 2 - 3 } & Tris-HCl $(\mathrm{pH} 8.0)$ & $60 \%$ \\
\cline { 2 - 3 } & HEPES-NaOH $(\mathrm{pH} 7.0)$ & $97 \%$ \\
\hline
\end{tabular}

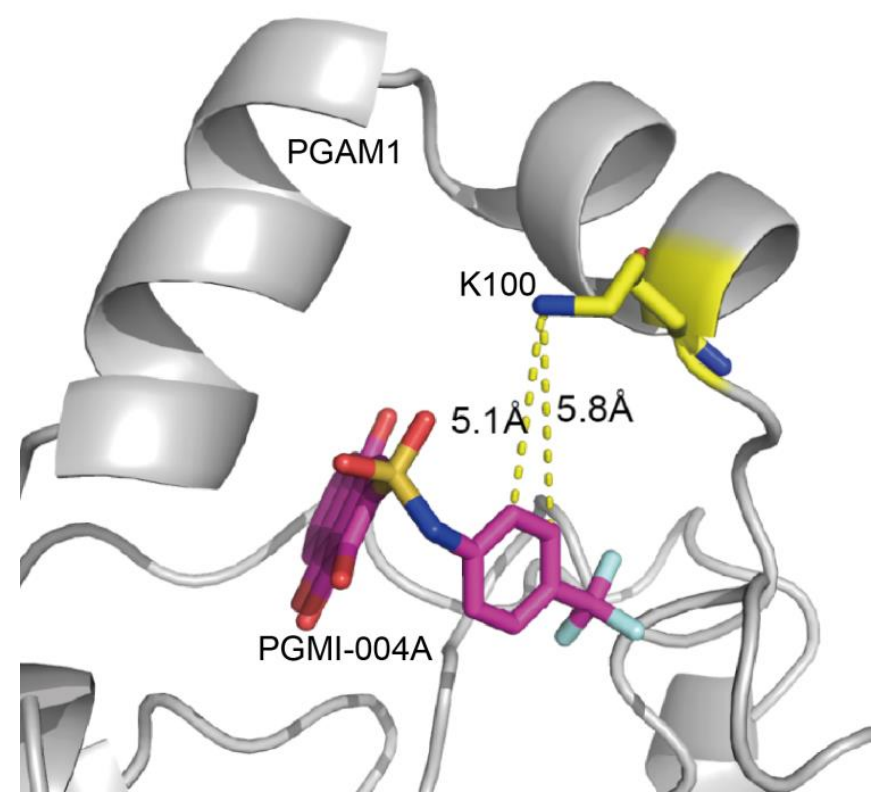

Figure S1 Structure based design of compound KHAc from the co-crystal structure of PGAM1 and PGMI-004A (PDB: 5Y2I). The site of the acetoxy group was selected by 
carefully checking the distances between the ligand and surrounding residues when the ligand is bound to the active site of PGAM1.
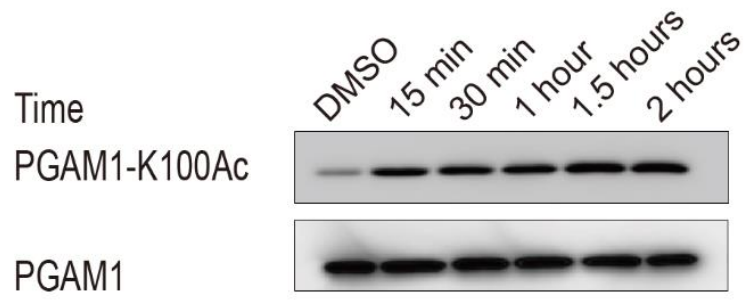

Figure S2 Time-dependent acetylation of rPGAM1 K100 with the treatment of KHAc (2 hours) detected by western blot using a K100 acetylation specific antibody.

a

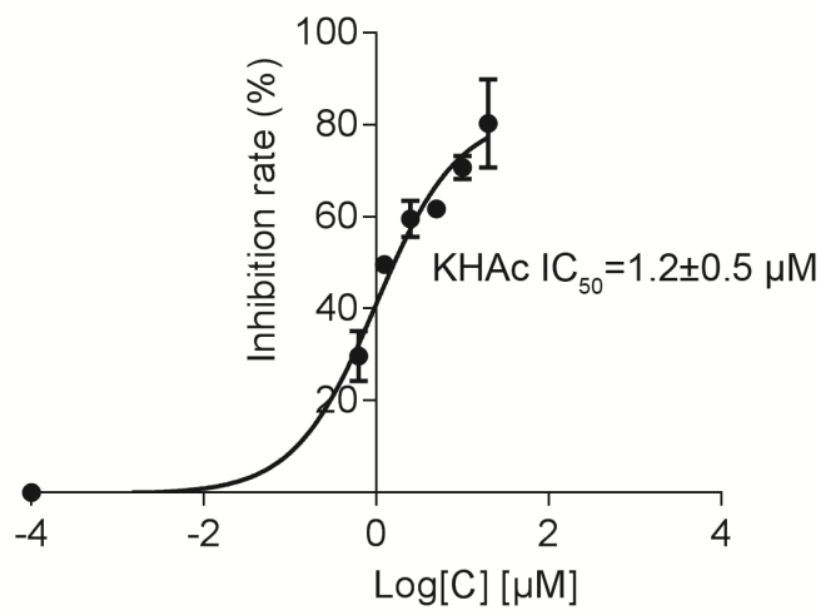

b

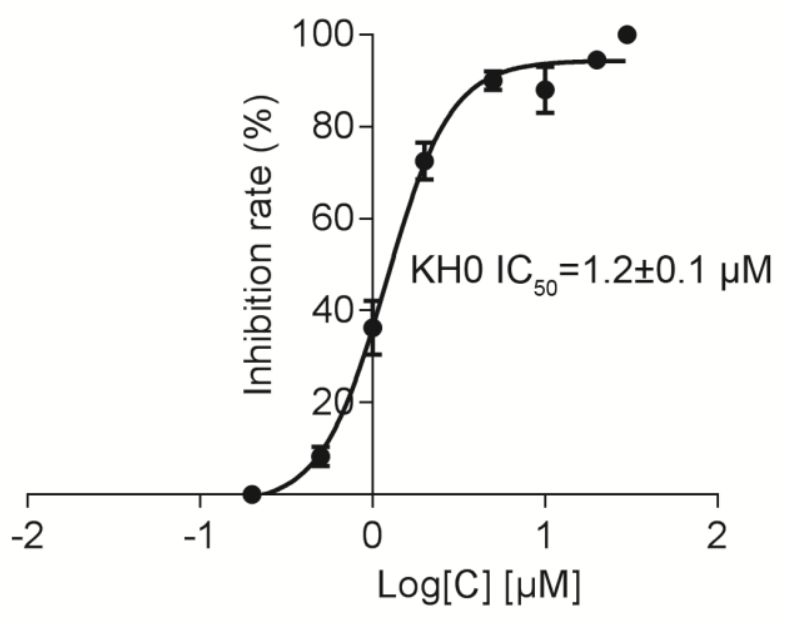

Figure S3 The $\mathrm{IC}_{50}$ measurement of KHAc and $\mathrm{KHO}$ 
a

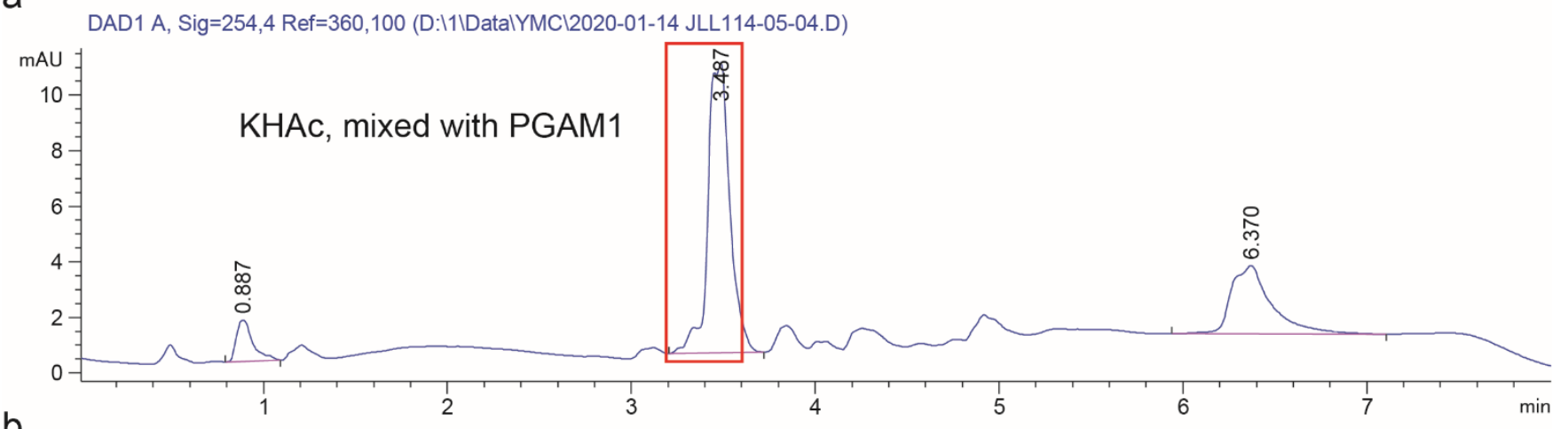

b

DAD1 A, Sig=254,4 Ref=360,100 (D:I1IDatalYMCI2020-01-14 JLL214-05-14.D)

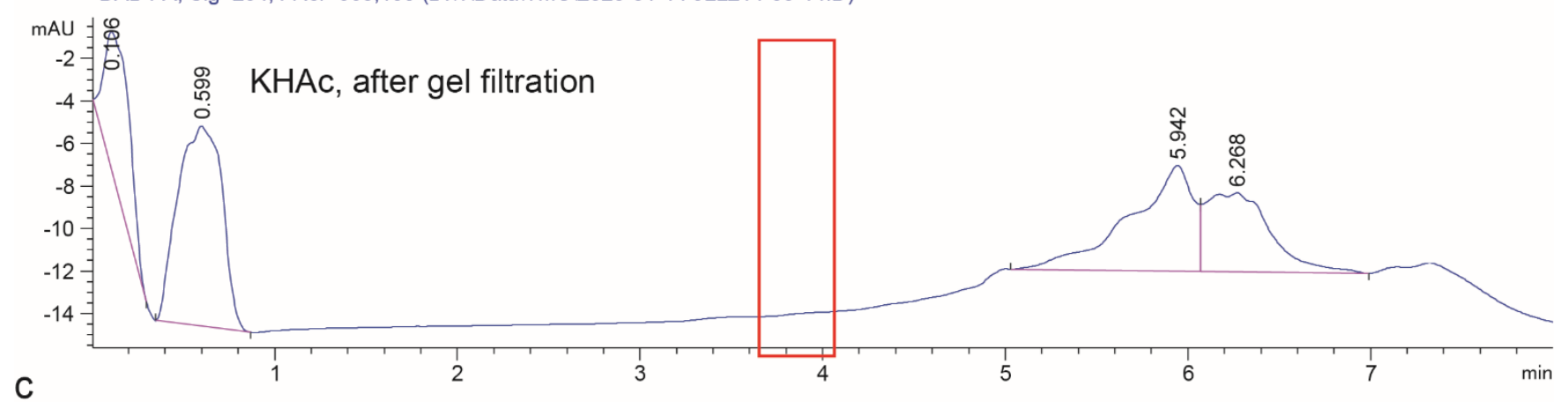

C

DAD1 A, Sig=254,4 Ref=360,100 (D:I11DatalYMCI2020-01-14 JLL515-50-42.D)

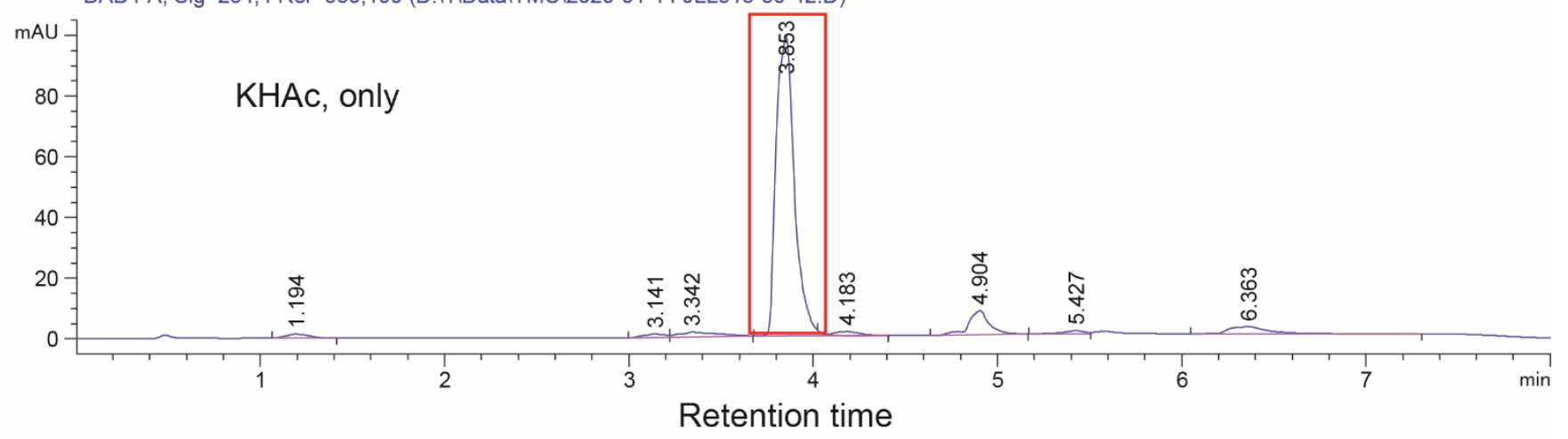


d

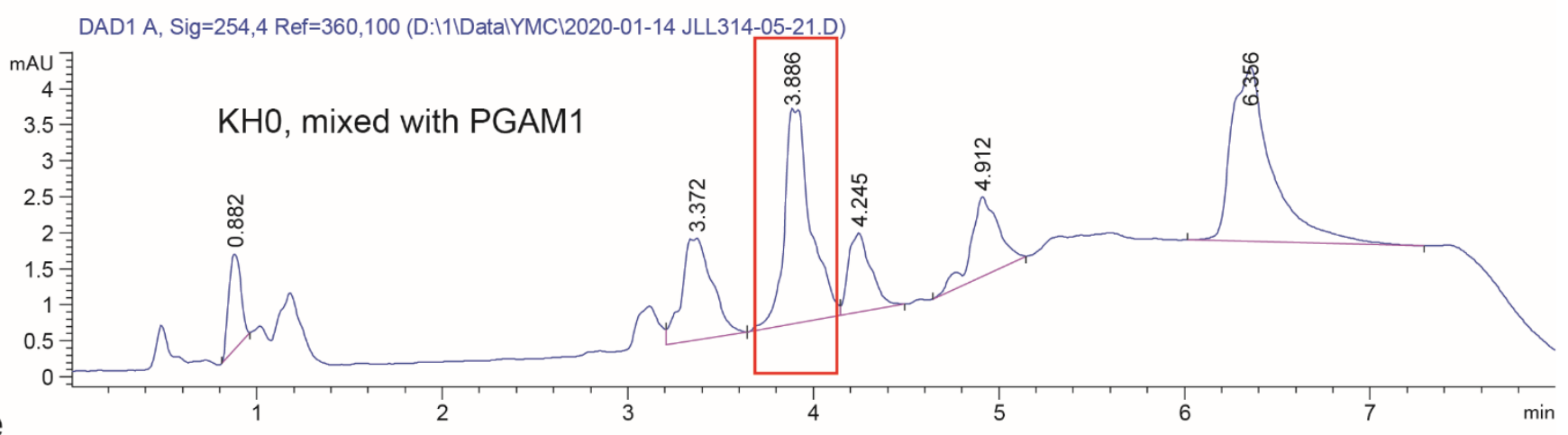

e

DAD1 A, Sig=254,4 Ref=360,100 (D:I11DatalYMCI2020-01-14 JLL414-05-27.D)

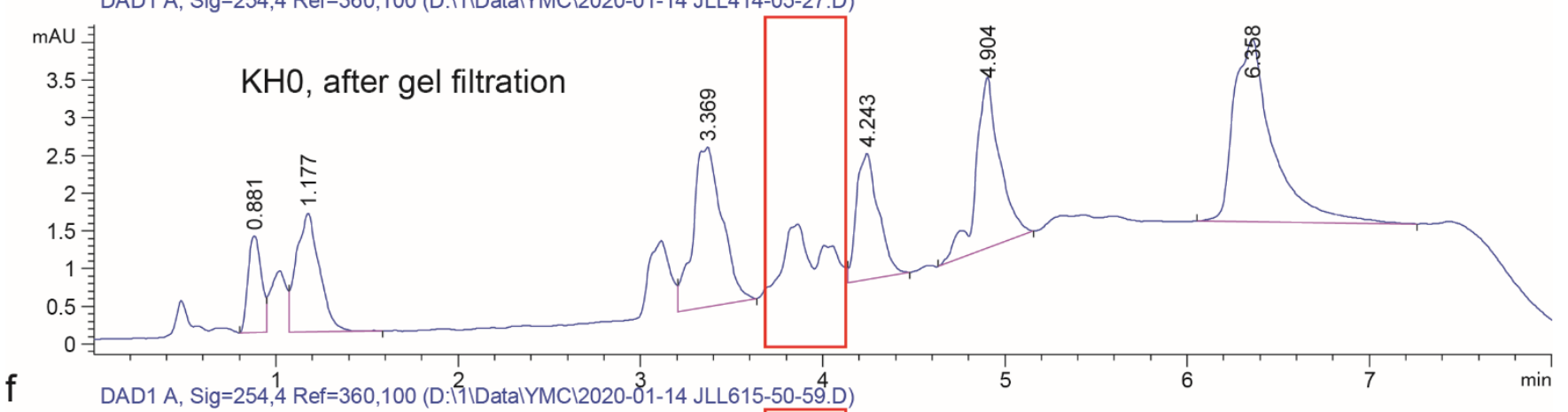

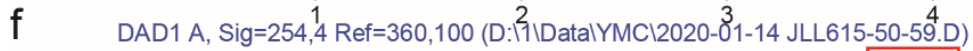

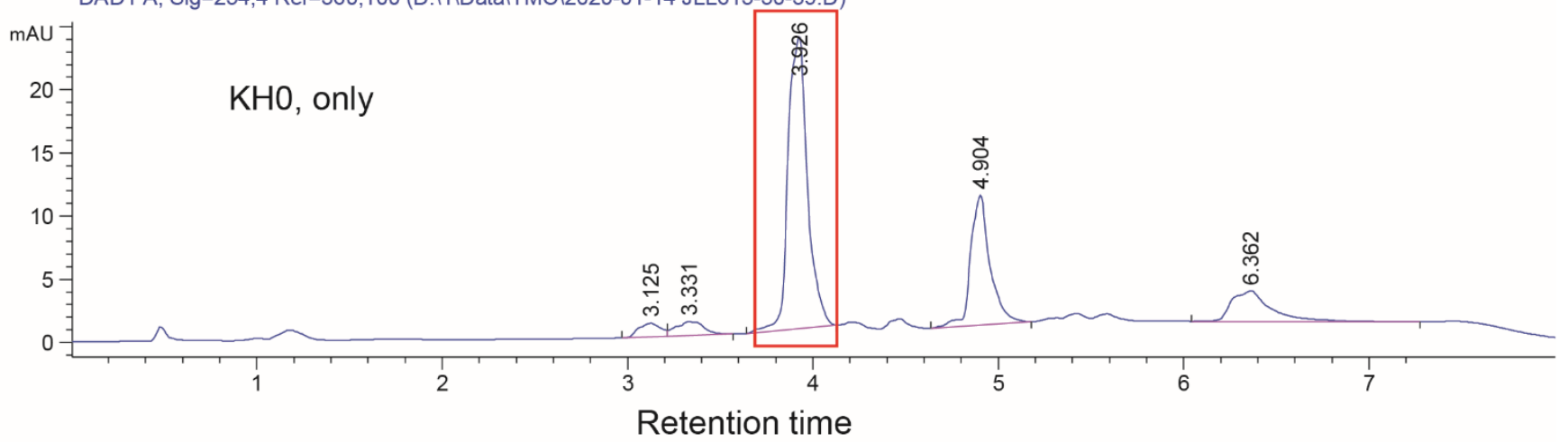

Figure S4. The measurement of KHAc and KH0 by HPLC after gel filtration. a) rPGAM1 (6.7 $\mu \mathrm{M})$ was incubated with $\mathrm{KHAc}(10 \mu \mathrm{M})$ at the ratio of 1:1.5 for 2 hours. b) The incubated sample was purified by gel filtration. Protein fraction was collected and concentrated to $6.7 \mu \mathrm{M}$. c) KHAc $(10 \mu \mathrm{M})$ in methanol. d) rPGAM1 $(6.7 \mu \mathrm{M})$ was incubated with $\mathrm{KH} 0(10 \mu \mathrm{M})$ at the ratio of 1:1.5 for 2 hours. e) The incubated sample was purified by gel filtration. Protein fraction was collected and concentrated to $6.7 \mu \mathrm{M}$. f) $\mathrm{KHO}(10 \mu \mathrm{M})$ in methanol. 


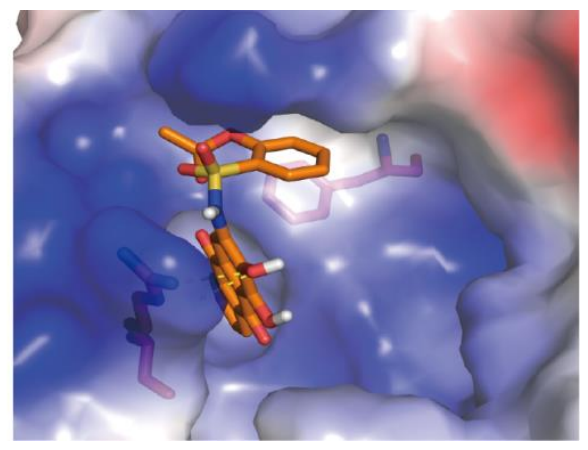

Figure S5 The potential diagram of the co-crystal between KHAc and PGAM1 showed that the main interaction between the compound KHAc and PGAM1 is hydrophobic interaction.

a

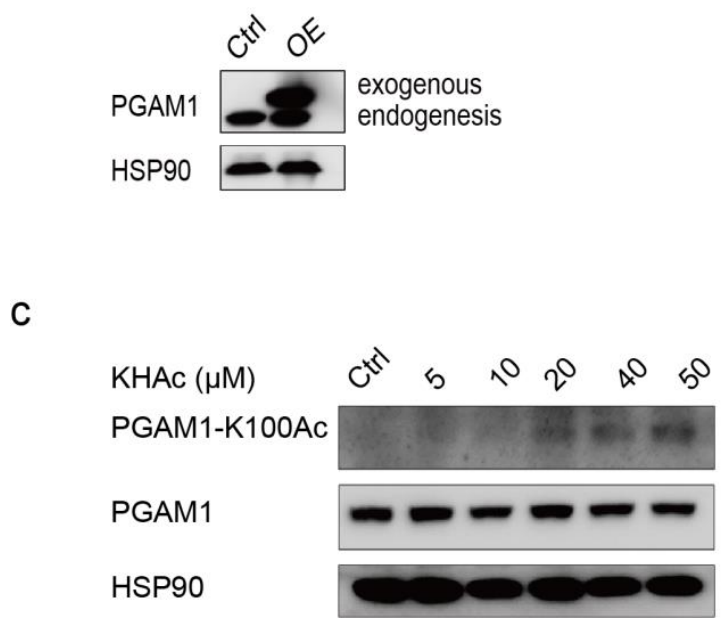

b

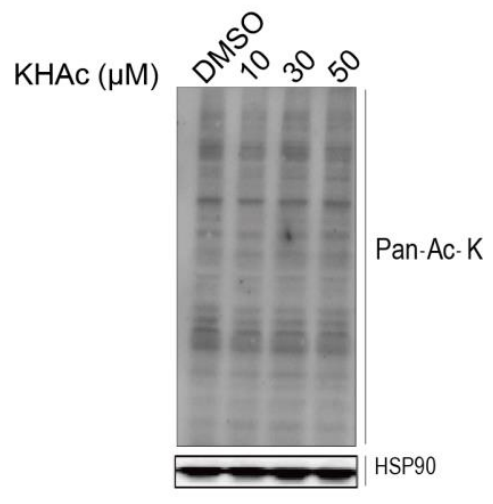

Figure S6 KHAc acetylates Lys100 of PGAM1 in cell lysates and living cells. a. Stable cell line HELA overexpressing 2FLAG-3C-PGAM1 was validated by western blot; b. Lysine acetylation of HELA intact cells were detected by western blot using a pan-acetylation antibody. The cells were treated with KHAc at various concentration; c. Concentrationdependent acetylation of K100 of native PGAM1 in HELA cells. 


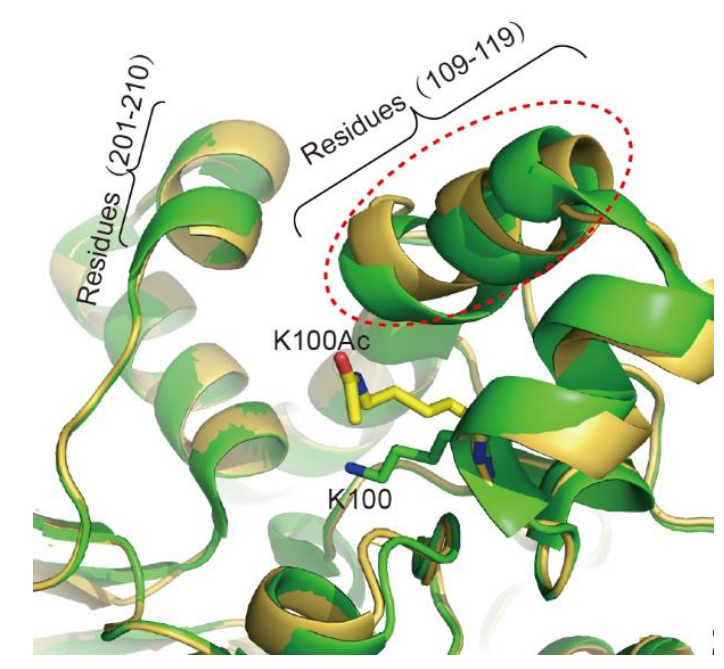

Figure S7 Acetylation of PGAM1 K100 induced the conformation change of the residues 109-119. Structure alignment of the apo-form of PGAM1 (green, PDB: 4GPZ) and K100Ac form (yellow, PDB: 5ZS7) revealed a conformational change of residues 109119 , spatially closed to residues 201-210 which is involved in ACTA2 binding.

\section{Expression and purification of $6 \times$ His-tag PGAM1}

$6 \times$ His-tagged PGAM1 was purified from prokaryotic expression system. The plasmid was gifted from Department of Chemistry and Institute for Biophysical Dynamics, University of Chicago, Chicago ${ }^{[2]}$ and overexpressed in DH5 $\alpha$ competent E. coli cells. The plasmid DNA was added to the competent BL21 cells and incubated on ice for $30 \mathrm{~min}$. Cells were heat-shocked at $42^{\circ} \mathrm{C}$ for $30 \mathrm{~s}$, followed by 2 min incubation on ice. $950 \mu \mathrm{lLB}$ medium was added and the mixture was incubated for 1 hour at $37^{\circ} \mathrm{C} .40 \mu \mathrm{l}$ of the mixture was plated on LB agar supplemented with ampicillin and incubated overnight at $37^{\circ} \mathrm{C}$. The following day, a singlecolony was used to inoculated an overnight in 10ml LB mediun, which was used to inoculated 1L YT selective medium., C. The culture was grown at $37^{\circ} \mathrm{C}$ with $180 \mathrm{rpm}$ agitation to an OD600 of 0.8 and induced with $0.5 \mathrm{mM}$ IPTG as described previously ${ }^{[3]}$. After further incubation for 16 hours at $18^{\circ} \mathrm{C}$ the recombinant protein PGAM1 (rPGAM1) was expressed in E. coli cells. The culture was pelleted and lysed. 
After centrifuged at $4^{\circ} \mathrm{C}$ with $12000 \mathrm{rpm}$, the supernatant was loaded onto Ni-NTA column. The protein of $6 \times$ FLAG PGAM1 was eluted using elution buffer and then subjected to size exclusion purification. All the purification method was referred to the report previously ${ }^{[3]}$. The stocking buffer of rPGAM1 was $20 \mathrm{mM}$ Tris- $\mathrm{HCl}$ (pH 8.0), $150 \mathrm{mM} \mathrm{NaCl}$ and $1 \mathrm{mM}$ DTT.

\section{Enzymatic assay of PGAM1 in vitro}

The activity of rPGAM1 was measured by multiple enzymes coupled assay described as previously $^{[3]} .0 .015 \mathrm{mg} / \mathrm{ml} \mathrm{rPGAM} 1$ was incubated with KHAc $(2.5 \mu \mathrm{M}, 5 \mu \mathrm{M}, 10 \mu \mathrm{M})$ as an enzyme mixture, and the activity was measured at different incubation time point. Briefly, $1 \mu$ enzyme mixture was mixed with $49 \mu 100 \mathrm{mM}$ Tris- $\mathrm{HCl}(\mathrm{pH}$ 8.0) buffer in 96-well plates and incubated for 2 min. Subsequently, $49 \mu$ solution B containing $100 \mathrm{mM} \mathrm{KCl}, 5 \mathrm{mM} \mathrm{MgCl} 2,1 \mathrm{mM}$ ADP, $0.2 \mathrm{mM}$ NADH, 0.5 units. $\mathrm{ml}^{-1}$ enolase, 0.5 units. $\mathrm{ml}^{-1}$ recombinant pyruvate kinase $\mathrm{M} 1$, and 0.1 units. $\mathrm{ml}^{-1} \mathrm{LDH}$ were added to the enzyme mixture. At last, $1 \mu 1200 \mathrm{mM} 3$-PG was added to the above mixture to initiate the reaction (the final concentration of KHAc is $25 \mathrm{nM}, 50 \mathrm{nM}, 100$ $\mathrm{nM}$ respectively, the final concentration of rPGAM1 is $5 \mathrm{nM}$ ). The decrease in absorbance at $340 \mathrm{~nm}$ from the oxidation of NADH was measured by a microplate reader to represent PGAM1 activity (Figure. 2d). For the activity measurement in Fig. 2e, rPGAM1 (6.7 $\mu \mathrm{M})$ was incubated with KHAc or KH0 $(10 \mu \mathrm{M})$ with mole ratio of 1:1.5, respectively. After overnight incubation, the two samples were subjected to size exclusion chromatography to remove the compounds. The protein was concentrated to $0.015 \mathrm{mg} \cdot \mathrm{ml}^{-1}$ for further activity measurement as described above.

\section{The calculation of enzyme kinetic parameters $K_{i}$ and $K_{\text {inact }}{ }^{[4]}$}

Generally speaking, irreversible or covalent inhibition function occurs in two steps. Firstly, the inhibitor binds to the target protein, processed as the reversible inhibitor. Secondly, the activity group of the inhibitor reacting with enzyme necessary residue, means to modify the protein residue. As a result, the modification leads the irreversible inhibition. $\mathrm{K}_{\mathrm{i}}$ means the capability to form the complex between inhibitor and enzyme. $\mathrm{K}_{\text {inact }}$ means 
the capability to form the covalent bond between the irreversible inhibitor and enzyme. The two step mechanism can be shown as the formula below.

$$
\mathrm{E}+\mathrm{I} \stackrel{\mathrm{KI}}{\rightleftharpoons}[\mathrm{E}-\mathrm{I}] \stackrel{\text { Kinact }}{\longrightarrow} \mathrm{El}
$$

\section{E: Enzyme}

\section{I: Inbibitor}

The enzyme kinetic parameters $\mathrm{K}_{\mathrm{i}}$ and $\mathrm{K}_{\text {inact }}$ can be calculated using the followed formula.

(1) $\%$ Total Occupancy $=100\left(1-\exp \left(-\mathrm{K}_{\mathrm{obs}}{ }^{*}\right.\right.$ time $)$

(2) $\mathrm{K}_{\mathrm{obs}}=\mathrm{K}_{\text {inact }}[$ Inbibitor $] /\left(\mathrm{K}_{\mathrm{i}}+[\right.$ Inhibitor $\left.]\right)$

The irreversible inhibitor has time-dependent characteristics. Therefore, we calculate the $\mathrm{K}_{\mathrm{obs}}$ use the formula (1). The total occupancy means the inhibition at the given time and the corresponding concentration inhibitor. After calculate the corresponding concentration $\mathrm{K}_{\text {obs. }}$. We use the formula (2) to calculate the $\mathrm{K}_{\text {inact }}$ and $\mathrm{K}_{\mathrm{i}}$ by transfer the formula to logarithm. The result $\mathrm{K}_{\mathrm{i}}$ calculate as the micromolar level, means the compound KHAc can strongly interact with the enzyme PGAM1.

\section{Analysis of rPGAM1 lysine acetylation by LC-MS/MS}

$300 \mu \mathrm{M}$ rPGAM1 was treated with $450 \mu \mathrm{M}$ KHAc at room temperature overnight. The same amount of rPGAM1 was incubated with 1\% DMSO (v/v) as a negative control. Proteins were precipitated with TCA (trichloroacetic acid). The protein pellet was subjected to vacuum drying. Subsequently, the pellet was dissolved with $8 \mathrm{M}$ urea in $100 \mathrm{mM}$ Tris$\mathrm{HCl}(\mathrm{pH} 8.5$ ). The solution was added with TCEP (final concentration : $5 \mathrm{mM}$ ) and Iodoacetamide (the final concentration is $10 \mathrm{mM}$ ) and incubated at room temperature for 20 and 15 minutes for reduction and alkylation, respectively. The solution was diluted four 
times and digested with Trypsin at 1:50 (w/w) (Promega, http://www.promega.com/). The peptide mixture was desalted and loaded onto a home-made $15 \mathrm{~cm}$-long pulled-tip analytical column (75 $\mu \mathrm{m}$ i.d.), which packed with $3 \mu \mathrm{m}$ reverse phase beads (Aqua C18, Phenomenex, Torrance, CA) connected to an Easy-nLC 1000 nano HPLC (Thermo Scientific, San Jose, CA) for mass spectrometry analysis. Data-dependent tandem mass spectrometry (MS/MS) analysis was performed with a Q Exactive Orbitrap mass spectrometer (Thermo Scientific, San Jose, CA). Peptides eluted from the LC system were directly electrosprayed into the mass spectrometer with a distal $1.8-\mathrm{kV}$ spray voltage. One acquisition cycle includes one full-scan MS spectrum (m/z 300-1800) followed by top 20 MS/MS events, sequentially generated on the first to the twentieth most intense ions selected from the full MS spectrum at a $27 \%$ normalized collision energy. MS scan functions and LC solvent gradients were controlled by the Xcalibur data system (Thermo Scientific). The acquired MS/MS data were analyzed against a UniProtKB database using Integrated Proteomics Pipeline (IP2, http://integratedproteomics.com/). Spectrum counts were used for lysine acetylation quantitation.

\section{Concentration-dependent acetylation of PGAM by KHAc}

The concentration of the recombinant protein rPGAM1 was measured by BSA standard curve by using the BCA Protein Assay kit (CW00145). The final concentration of rPGAM1 was diluted to $1 \mathrm{mg} \cdot \mathrm{ml}^{-1}$ and incubated with KHAc or DMSO as negative control overnight. The two samples were added with loading buffer and then subject to $10 \%$ SDS-PAGE. The antibody specifically recognizing PGAM1 K100Ac was generated. The putative acetylation peptide sequence is GLTGLNK(Ac)AETAA. rPGAM1 was treated by different concentration of KHAc to test the concentration-dependent acetylation of rPGAM1. Time-dependent acetylation of PGAM1 by KHAc

For time-dependent acetylation of PGAM1 by KHAc. The concentration of the recombinant protein PGAM1 was measured by BSA standard curve using the BCA Protein Assay 
kit (CW0015). The final concentration of rPGAM1 was diluted to $1 \mathrm{mg} / \mathrm{ml}$. Then, $2 \mu \mathrm{M}$ KHAc was incubate with rPGAM1, while DMSO was incubated with rPGAM1 as negative control. At different incubation time (15 $\mathrm{min}, 30 \mathrm{~min}, 1$ hour, 1.5 hours, 2 hours), the protein sample was added $1 \times$ loading buffer to stop the reaction. Subsequently, all the samples was subjected to western blot to detect the acetylation level change of PGAM1.

\section{Crystallization, data collection and structure analysis}

The crystal of PGAM1 was obtained by using hanging drop vapor diffusion method at $16^{\circ} \mathrm{C}$ in the crystallization reagent containing $100 \mathrm{mM}$ MES 6.0 and 8\% PEG3350 (v/v) as previously reported ${ }^{[5]}$. For obtaining the co-crystal of PGAM1 with KHAc and the crystal of PGAM1 K100Ac, the crystal of PGAM1 were soaked in reservoir solution containing $500 \mu \mathrm{M}$ KHAc for hours. Crystals were then cryo-protected by brief immersion in the cryoprotectant buffer containing $24 \%$ (v/v) glycerol prior to flash-frozen in liquid nitrogen.

Diffraction data were collected at the beamline of BL17U1, BL18U1 and BL19U1 in Shanghai Synchrotron Radiation Facility (SSRF). The data were processed with HKL3000 ${ }^{[5]}$ and the scaled data was used for molecular replacement by CCP4 ${ }^{[6]}$ using an initial model of PGAM1 derived from PDB entry 4GPZ. The structures were then refined by using Phenix ${ }^{[7]}$. The ligand restraints were built by using optimization workbench (eLBOW) in Phenix. Manual rebuilding of the model was carried out by using the molecular graphics programs $\mathrm{COOT}^{[8]}$ according to the electronic density. Water molecular was in-

corporated into the model when the structure was refined. All the graphs were made by using Pymol.

Generation of lentiviral plasmid for overexpressing $2 \times$ FLAG-3C-PGAM1 and the mutant 
The primers designed for encoding the long transcription of PGAM1 that has an overlap at the restriction enzyme sites AgeI/EcoRI with the mammalian lentiviral vector pLVX2FLAG-3C gifted from F.X Yu laboratory from Institutes of Biomedical Sciences, Fudan University and were synthesized in Huagene Biotechnology Company. The long transcription of PGAM1 cDNA was amplified by PCR from HEK293A cell cDNA genome. By using the Gibson DNA ligase (NEB, \#2611), the target gene fragment of the long transcription of PGAM1 was connected with the pLVX-2FLAG-3C vector. Subsequently, the fusion mixture was added into the competent cells and incubated on ice for $30 \mathrm{~min}$. Cells were heat-shocked at $42^{\circ} \mathrm{C}$ for $30 \mathrm{~s}$, followed by 2 min incubation on ice. $950 \mu \mathrm{L}$ LB medium was added and the mixture was incubated for 1 hour at $37^{\circ} \mathrm{C} .40 \mu$ the mixture was plated on the selected LB agar and incubated overnight at $37^{\circ} \mathrm{C}$. The following day, single colonies were selected,inoculated into $10 \mathrm{ml} \mathrm{LB}$ medium and grown overnight at $37^{\circ} \mathrm{C}$. The culture was grown at $37^{\circ} \mathrm{C}$ with $180 \mathrm{rpm}$ agitation to an OD600 of 1.2 . The plasmid of pLVX-2FLAG-3C-PGAM1 was extracted by using the plasmid Miniprep kit (TEGEN, \#DP103) followed by confirming the plasmid through DNA sequencing. We obtained the site-specific mutant plasmid of PGAM1 K100Q/K100R from the plasmid pLVX-2FLAG3C-PGAM1 according to the manufacturer protocol of Quick change kit (TRANSGEN BIOTECH, \#FM111-02)

\section{The Primer we used in the experiment}

pLVX-2FLAG-3C-PGAM1-long-transcription

Primer-F: CCAGGGGCCCACCGGTAGGCACAGGTATTTGGCCT

Primer-R: CCAGGGGCCCACCGGTATGGCCGCCTACAAACT

pLVX-2FLAG-3C-PGAM1-long-transcription K100Q

Primer-F: 5'-GCAGCAGTTTCTGCTTGATTGAGACCGGTTAGACC-3'

Primer-R: 5'-GGTCTAACCGGTCTCAATCAAGCAGAAACTGCTGC-3' 
pLVX-2FLAG-3C-PGAM1-long-transcription K100R

Primer-F: 5'-CAGCAGTTTCTGCTCGATTGAGACCGGTTAGACCCCCAT-3'

Primer-R: 5'-ATGGGGGTCTAACCGGTCTCAATCGAGCAGAAACTGCTG-3'

\section{PGAM1 acetylation measurement in cell lysate}

HEK293A cells were cultured in a $10 \mathrm{~cm}$ culture dish and grown to a density of $60 \%$ $80 \%$. Before transfection, the culture medium was changed with DMEM (Dulbecco's Modified Eagle Medium) without serum and antibiotics. After half an hour, the plasmid of pLVX-2FLAG-3C-PGAM1 was transiently transfected into the HEK293A cells with the Lipofectamine 2000 reagent according to the manufacturer's protocol. After 4 hours transfection, the culture medium of DMEM serum-free was changed with DMEM with 5\% (v/v) Gibco FBS, 100 units. $\mathrm{ml}^{-1}$ penicillin, and $100 \mathrm{mg} \cdot \mathrm{ml}^{-1}$ streptomycin. The HEK293A cells were pelleted in a $15 \mathrm{ml}$ centrifuge tube after overnight growth. $10 \mathrm{ml}$ precooling PBS buffer containing PMSF and protease inhibitor with a ratio of 1/100 was used to suspend the cells. The cell suspension was dispensed into the $1.5 \mathrm{ml}$ centrifuge tube labeled forehead with $1 \mathrm{ml}$ per portion. Then, the samples were lysed by three freezing and thawing cycles using liquid nitrogen and $37^{\circ} \mathrm{C}$ water bath ${ }^{[9]}$ and the cell lysates were centrifuged at $12000 \mathrm{rpm}, 4^{\circ} \mathrm{C}$. Supernatants $(800 \mu \mathrm{l})$ taken from each tube were treated with KHAc in a concentration-dependent manner at $37^{\circ} \mathrm{C}$ overnight. Then, the supernatant was subjected to immunoprecipitation by using the Flag beads and the acetylation levels were evaluated by using the generated PGAM1 K100Ac antibody. 


\section{Generation of stable cell lines of HELA overexpressing PGAM1}

For the overexpressing cell lines of HELA, the lentiviral was produced by co-transfecting the two package vector of pSPAX2 and pMD2.G with the two indicated plasmids pLVX-2FALG-3C-PGAM1 or the empty vector into the HEK293A cell lines, respectively. The lentiviral supernatant was harvested after 48 hours transfection and centrifuged at $3000 \mathrm{rpm}, 3 \mathrm{~min}$. Then, HELA cells were infected by the lentiviral supernatant and the Polybrene was added at the final concentration of $10 \mu \mathrm{g} \cdot \mathrm{ml}^{-1}$ to increase the infection efficiency. The second day, HELA cells were infected by the lentiviral supernatant again for another 24 hours. After the second time infection, the stable cell lines of HELA transfected with the plasmids of pLVX-2FALG-3C-PGAM1 and empty vector

were screened by using the antibiotic of puromycin at the final concentration of $2 \mu \mathrm{g} \cdot \mathrm{ml}^{-1}$ for two days and sub-cultured the cell lines. At last, Western blot assay was performed to confirm the success of the stable cell lines (Figure S6a).

\section{PGAM1 acetylation measurement in living cells}

For PGAM1 acetylation measurement in living cells, stable cell lines of HELA expressed 2FLAG-3C-PGAM1 were treated with liposome encapsulated KHAc overnight and then washed three times with PBS buffer followed by adding RIPA buffer ( $1 \mathrm{ml} /$ well) to lysed the cells. The cell lysates were collected for immunoprecipitation. The samples were analyzed by western blot using the generated antibody (antigen peptide sequence: GLTGLNKAETAA) that specifically recognizes the PGAM1 K100Ac. The global acetylation levels were also measured by western blot using pan-acetylation antibody.

PGAM1 mutants acetylation measurement in HEK293A cell lines 
For the cell lines of HEK293A transiently overexpressing the two PGAM1 mutants (K100Q and K100R), we transiently transfected the two mutant plasmids of PGAM1 by using Lipofectamine 2000 reagent according to the manufacturer's protocol. In order to characterize and confirm the specificity of the antibody anti-K100Ac the two PGAM1 mutant plasmids were used. After generated the two mutant cell lines of HEK293A. The two cell lines were treated overnight with100 uM KHAc encapsulated with liposome or liposome only. The following day, the cell lines were treated following the procedures used in the acetylation in living cells of HELA stable overexpressing PGAM1.

\section{KHAc-5C-N $\mathrm{N}_{3}$ pulldown assay in cell lysate}

Stable cell lines of HELA expressing 2FLAG-3C-PGAM1 ( $10^{7}$ cells $)$ were pelleted in a $1.5 \mathrm{ml}$ centrifuge tube. The cells were suspended with $1 \mathrm{ml}$ lysis buffer $(20 \mathrm{mM}$ Tris- $\mathrm{HCl}$ (pH 8.0), $100 \mathrm{mM} \mathrm{NaCl}, 1 \mathrm{mM}$ DTT). Subsequently, the samples were lysed by three freezing and thawing cycles using liquid nitrogen and $37^{\circ} \mathrm{C}$ water bath ${ }^{[9]}$ and the cell lysates were centrifuged at $4^{\circ} \mathrm{C}, 12000 \mathrm{rpm}$. Supernatant (400 $\left.\mu \mathrm{l}\right)$ was treated with $1 \%(\mathrm{v} / \mathrm{v})$ DMSO or KHAc-5C-N 3 (final concentration: $20 \mu \mathrm{M}$ ) and incubated overnight. On the second day, DBCO-PEG4-Biotin (final concentration: $50 \mu \mathrm{M}$ ) was added to the mixture for click reaction overnight. On the third day, the strep-Tactin@superflow beads were added to the mixture and incubated overnight. The beads were then washed with the western/IP buffer and analyzed by silver staining and western blot.

\section{The immunofluorescence assay}

The stable cell lines of HELA expressed 2FLAG-3C-PGAM1 were growing in the 6-well plates and treated with KHAc, KH0 (both encapsulated with lipsome) or liposome onlyas control overnight. The next day, cells grown on the cover glasses were fixed with $4 \%(\mathrm{v} / \mathrm{v})$ paraformaldehyde in PBS for $10 \mathrm{~min}$ at room temperature, washed three times with TBST and permeabilized with TBST containing $0.1 \%(\mathrm{v} / \mathrm{v})$ Triton $\mathrm{X}-100$ for $30 \mathrm{~min}$ at room 
temperature. After the cover glasses were washed three times with TBST, cells were blocked with $5 \%(\mathrm{v} / \mathrm{v})$ bovine serum albumin (TBST containing 5\% (v/v) bovine serum albumin) at room temperature for $30 \mathrm{~min}$ and incubated with Texas Red-conjugated phalloidin to stained F-actin. Afterwards, the cover glasses were washed three times with TBST. Then diulute the DAPI stock solution to $300 \mathrm{nM}$ in TBST. Add approximately $200 \mu$ lof this dilute DAPI staining solution to the cover glasses, making certain that the cells were completely covered and incubated for $30 \mathrm{~min}$. After that, the cover glasses were washed for three times with TBST. Mount the cover glasses onto the slides. Use about $7 \mu$ lmounting medium per coverslip (Invitrogen ProLong Gold with antifade reagent, P36931). Seal with nail polish after mounting media solidified overnight. At last, obtain the images captured by laser scanning confocal microscopy. Bar, $0.05 \mathrm{~mm}$.

\section{Antibody used in the experiment}

Flag (Sigma, \#F3040), PGAM1 (Abcam, \#ab2220), Hsp90 (Cell signaling Technology, \#4877), Pan-acetylation antibody (Cell signaling Technology, \#9681S), anti-acetylPGAM1 K100 antibody (antigen peptide sequence: GLTGLNKAETAA) was generated at Shanghai YOUKE BIOTECH.

\section{Acession codes}

PGAM1 complex with KHAc (2 hours): 5ZRM

PGAM1 complex with KHAc (7 hours): 5ZS8

PGAM1 K100Ac (18 hours): 5ZS7 


\section{REFERENCES}

[1] Antonello,C.U., Eugenio;Palumbo,Manlio. (1989) Arch. Pharm. 322, $541-544$.

[2] Wang Y., Wei Z.,Liu L., Cheng Z., Lin Y., Ji, F., Gong, W. (2005) Biochem. Bioph. Res. Commun. 331, 1207-1215.

[3] Hitosugi, T., Zhou, L., Elf, S., Fan, J., Kang, B.H., Seo, J., Shan, C., Dai, Q., Zhang, L., Xie J., Gu T., Jin, P., Aleckovic, M., LeRoy, G., Kang, Y., Sudderth, J., DeBerardinis, R., Luan, C., Chen, G., Muller, S., Shin, D., Owonikoko, T., Lonial, S., Arellano, M., Khoury, H., Khuri, F., Lee, B., Ye, K., Boggon, T., Kang, S., He, C., Chen, J. (2012) Cancer. Cell. 2012, 22, 585-600.

[4] Strelow, J. M. (2016) Slas Discov. 33, 3-30

[5] Otwinowski, Z., and Minor, W. (1997) Method. Enzymol. 276, 307-326.

[6] Winn, M. D., Ballard, C. C., Cowtan, K. D., Dodson, E. J., Emsley, P., Evans, P. R., Keegan, R. M., Krissinel, E. B., Leslie, A. G. McCoy, A., McNicholas, S. J., Murshudov, G. N., Pannu, N. S., Potterton, E. A., Powell, H. R., Read, R. J., Vagin, A., Wilson, K. S. (2011) Acta Crystallogr. D. 67, 235-242.

[7] Liebschner, D., Afonine, P. V., Baker, M. L., Bunkoczi, G., Chen, V. B., Croll, T. I., Hintze, B., Hung, L. W., Jain, S., McCoy, A. J., Moriarty, N. W., Oeffner, R. D., Poon, B. K., Prisant, M. G., Read, R., J., Richardson, J. S., Richardson, D. C., Sammito, M. D., Sobolev, O. V., Stockwell, D. H., Terwilliger, T. C., Urzhumtsev, A. G., Videau, L. L., Williams. C. J. and Adams, P. D. (2019) Acta cryst, D. 75, 861-877

[8] Emsley, P., and Cowtan, K. (2004) Acta Crystallogr. D. 60, 2126-2132.

[9] Guo, Z., Zheng, T., Chen, B., Luo, C., Ouyang, S., Gong, S., Li, J., Mao, L., Lian, F., Yang, Y., Huang, Y., Li, L., Lu, J., Zhang, B., Zhou, L., Ding, H., Gao, Z., Zhou, L., Li, G., Zhou, R., Chen, K., Liu, J., Wen, Y., Gong, L., Ke, Y., Yang, S., Qiu, X., Zhang, N., Ren, J., Zhong, D., Yang, C., Liu, J., and Jiang, H. Cancer Cell 2016, 30, 474-484. 